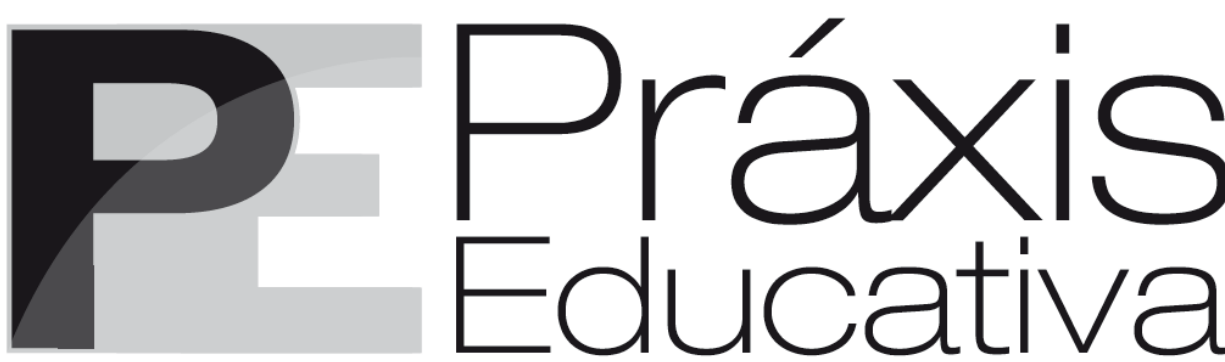

ISSN 1809-4031

elSSN 1809-4309

http://dx.doi.org/10.5212/PraxEduc.v.14n3.016

\title{
Movimento secundarista: do esgotamento à invenção curricular
}

\section{Movement of secondary school: from exhaustion to curricular invention}

\section{Movimiento del secundario: del agotamiento a la invención curricular}

\author{
Débora Reis Pacheco* \\ Millena Nascimento da Silva ${ }^{* *}$
}

\begin{abstract}
Resumo: Este artigo tem como objetivo descrever invenções curriculares, a partir do esgotamento de estudantes que marcaram movimentos estudantis, especialmente em torno das ocupações das escolas estaduais de São Paulo em 2015 e 2016. Ressalta-se que a ideia de esgotamento parte dos questionamentos de Gilles Deleuze sobre modos de existência que se tornam intoleráveis. Do mesmo modo, a ideia de criação/invenção também vem ao encontro das ideias desse filósofo, se compondo a deslocamentos de outros autores, como Marlucy Alves Paraíso, sob a temática do currículo. O texto foi construído em uma cartografia em que as autoras misturaram diferentes fontes e experiências para dar voz a outros currículos. Reconhece-se, então, um currículo-gente produzido nos espaços escolares por estudantes esgotados.

Palavras-chave: Movimento secundarista. Currículo. Esgotamento.
\end{abstract}

\begin{abstract}
This paper aims to explore curricular creations from the exhaustion of students that marked student movements, especially around the occupations of the state schools of São Paulo, Brazil, in 2015 and 2016. It is emphasized that the idea of exhaustion is part of the questions of Gilles Deleuze about modes of existence that become intolerable. In the same way, the idea of creation/invention also meets the ideas of this philosopher, composing itself to the displacements of other authors, such as Marlucy Alves Paraíso under the theme of the curriculum. The text was constructed in a cartography in which the authors mixed different sources and experiences to give voice to other curricula. A curriculum-people produced in school spaces by exhausted students is then recognized.
\end{abstract}

Keyword: Secondary school movement. Curriculum. Exhaustion.

Resumen: Este artículo tiene como objetivo describir invenciones curriculares, a partir del agotamiento de estudiantes que marcaron movimientos estudiantiles, especialmente en torno a las ocupaciones de las escuelas estatales de São Paulo, Brasil, en 2015 y 2016. Se resalta que la idea de agotamiento parte de los cuestionamientos de Gilles Deleuze sobre modos de existencia que se vuelven intolerables. De la misma manera, la idea de creación/invención también viene al encuentro de las ideas de ese filósofo, componiéndose a desplazamientos de otros autores, como Marlucy Alves Paraíso, bajo la temática del

\footnotetext{
* Doutoranda em Educação Matemática pela Universidade Federal de Mato Grosso do Sul (UFMS). E-mail: <debora.rpacheco@gmail.com>. ORCID: http://orcid.org/0000-0002-1051-3403

** Graduanda em Ciências Sociais pela Universidade de São Paulo (USP) - FFLCH. E-mail: <nascimento.millena@usp.br>. ORCID: https://orcid.org/0000-0002-2998-4387
} 
curriculum. El texto fue construido en una cartografía en que las autoras mezclaron diferentes fuentes y experiencias para dar voz a otros currículos. Se reconoce, entonces, un currículo-gente producido en los espacios escolares por estudiantes agotados.

Palabras clave: Movimiento del secundario. Curriculum. Agotamiento.

\section{Primeiras palavras}

Este texto, escrito a quatro mãos, reúne uma doutoranda em Educação Matemática e uma ex-secundarista estudante de Ciências Sociais e participante do movimento das ocupações das escolas de São Paulo. Um misto de experiências com um objetivo em comum: problematizar currículos escolares e visibilizar outras formas de inventar currículos a partir de movimentos estudantis, com destaque para as ocupações das escolas do estado de São Paulo de 2015 e 2016. É a partir de nossas experiências com esses movimentos que este texto se articula. Trata-se de uma escrita-experimento de uma tese ${ }^{1}$ em construção. Não é recorte, é processo. Trata-se de colocar em palavras uma conversa entre duas autoras que experienciaram as ocupações e os movimentos estudantis de modos e lugares diferentes.

Acreditamos que a publicação de textos como este constitui um dos caminhos de aproximação da academia com as lutas sociais e as manifestações políticas. Assim, buscamos aqui dialogar juntas sobre as ocupações estudantis e pensar em currículos-outros que emergiram ali, misturando os espaços acadêmicos em sua formalidade e as experiências narradas em sua coloquialidade.

Partindo da ideia de que há diferentes definições para currículo, antecipamos aqui nossas compreensões sobre o tema. Em primeiro lugar, é necessário destacar que não estamos nos referindo apenas às tradicionais listas de conteúdos, ementas de disciplinas ou documentos oficiais. Tomamos currículo como verbo que age nos espaços escolares com e sobre os estudantes, por meio de um conjunto heterogêneo de técnicas e de ferramentas variadas, sem deixar de incluir tais listas de conteúdos. Entendemos que, ao mesmo tempo que o currículo molda ou fortalece modos de existências, é também espaço de criação e de multiplicidade.

Um currículo está sempre cheio de ordenamentos, de linhas fixas, de corpos organizados, de identidades majoritárias. Porém um currículo, também, está sempre cheio de possibilidades de rompimento das linhas do ser; de contágios que podem nascer e se mover por caminhos insuspeitados; de construção de modos de vida que podem se desenvolver de formas particulares. Um currículo é um artefato com muitas possibilidades de diálogos com a vida; com diversas possibilidades de modos de vida, de povos e de seus desejos. É um artefato com um mundo a explorar. (PARAÍSO, 2010, p. 588).

Desse modo, entendemos que os secundaristas inventaram currículos durante os períodos em que ocuparam as escolas, já que tiveram que tomar decisões, fazer escolhas; assim, fazer os espaços escolares funcionarem mesmo que em condições diferentes das rotinas habituais.

É como se a escola estivesse "grávida" de outra, grávida de um outro currículo cujos construtores seriam os estudantes ao forçarem a introdução de novos conhecimentos a serem tratados na escola, mesmo ao exercer uma quebra na rotina "normal" de uma escola, como, por exemplo, ocupando-a. (SAN SEGUNDO; SEVERO, 2019, p. 7).

\footnotetext{
${ }^{1}$ Tese em andamento com título provisório: Corpo esgotado como potência de criação de currículo.
} 
Trata-se de um currículo que parte das estruturas convencionais, mas que fissura prescrições diante das necessidades do movimento secundarista. Assim, acreditamos que a invenção curricular desse período é potencializada por um estado de esgotamento no sentido deleuzeano (DELEUZE, 1992), como argumentaremos nas próximas linhas.

Tal esgotamento diz respeito a modos de existência que se tornam intoleráveis, diz respeito a um estado que se difere de um cansaço, "[...] pois entre o esgotamento sentado e o cansaço deitado, rastejante ou plantado, há uma diferença de natureza" (DELEUZE, 1992, p. 74). O cansaço está relacionado ao trabalho e à produção, em que, depois do descanso, é possível voltar a produzir. Já o esgotamento é pura “inação" (PELBART, 2016, p. 42). Por outro lado, o esgotamento é tampouco a renúncia do corpo e da mente, mas o desligamento do mundo em seus clichês que se tornam intoleráveis.

Nesse sentido, nosso texto organiza-se a partir da questão: Quais currículos podem emergir de um esgotamento estudantil?

\section{Nossos caminhos}

Para argumentarmos sobre a existência de uma invenção curricular durante as ocupações, a partir de um esgotamento, trazemos narrativas que reúnem dados produzidos em entrevistas com duas secundaristas, dados coletados em documentários e livros ${ }^{2}$.

A construção das narrativas que compõe nossos dados de análise entra pela porta dos fundos da ciência, para lembrar das distinções que Latour (2000) faz entre a ciência acabada e a ciência em construção. A entrada pelos fundos considera os bastidores da pesquisa, entendendo que tudo que acontece influencia a pesquisa e se mistura a ela em um processo inacabado.

O equipamento necessário para viajar pela ciência e pela tecnologia é, ao mesmo tempo, leve e variado. Variado porque é preciso misturar pontes de hidrogênio com prazos finais, exame da capacidade alheia com dinheiro, correção de sistemas de computadores com estilo burocrático. (LATOUR, 2000, p. 20).

Tudo se mistura no fazer pesquisa que transborda para esse texto. Não sabemos mais quem escreve e quem é "objeto" de estudo, uma estudante-secundarista da escola pública atuante nas ocupações não é mais sujeito de pesquisa, é autora, é palavra, é texto vestido de experiência. Do mesmo modo, a pesquisadora não pode mais olhar seus dados de fora, distante e sem afetarse.

Assim, nesse caminho percorrido a partir da porta dos fundos, os critérios tradicionais não cabem mais, a distância entre pesquisador e o observado é outra:

O equívoco deve-se ao significado de distância. A distância que devemos investigar não é entre observador e observado - exotismo barato -, mas entre os conteúdos do mundo antes e depois da pesquisa. Portanto, nem a distância nem a empatia são bons indicadores de que se fez boa ciência; é-o apenas este critério: será que temos, agora, alguma distância entre o novo repertório de acções e aquele com que começamos? Se sim, não foi tempo perdido; se não, gastou-se dinheiro em vão, e não interessa quão científicos, no sentido tradicional, pareçam os resultados (LATOUR, 2008, p. 52).

\footnotetext{
${ }^{2}$ Em especial o documentário Escolas em luta, dirigido por Rodrigo T. Marques, Tiago Tambelli, Eduardo Consonni, de 2017; o livro Escolas de Luta, de Antonia M. Campos, Jonas Medeiros e Márcio M. Ribeiro, editora Veneta, 2016; e o artigo A proposta de reorganização escolar do governo paulista e o movimento estudantil secundarista, de Evaldo Piolli, Luciano Pereira e Andressa de Sousa Rodrigues Mesko, de 2016.
}

Práxis Educativa, Ponta Grossa, v. 14, n. 3, p. 1085-1103, set./dez. 2019 Disponível em: <http://www.revistas2.uepg.br/index.php/praxiseducativa $>$ 
A partir dessa "distância", apresentamos duas narrativas produzidas pelas duas autoras deste artigo, em que observadora e observada se misturam em um processo de análise. Narrativas resultantes de experiências que se compõem pelos nossos afetamentos ao viver de dentro-fora as ocupações e outras situações relacionadas ao ambiente escolar, alimentados também pelo que ressoa de nossas leituras de livros, artigos e documentários apontados anteriormente.

A produção de tais narrativas "[...] serve-se de fontes as mais variadas, incluindo fontes não só escritas e nem só teóricas. Seus operadores conceituais podem surgir tanto de um filme quando de uma conversa ou de um tratado de filosofia" (ROLNIK, 2014, p. 65) Entendemos que a variedade de fontes contribui para um composto potente de análise que permite outro olhar para os movimentos estudantis, de modo que a distância entre o antes e o depois desta pesquisa faça valer a pena o processo que intitulamos de científico para caber nesta revista, provocando outras experiências e percepções entre nós e os leitores.

Vale ressaltarmos que nossa intenção não é revelar currículos inventados para proposição de um novo sistema escolar. Em uma tentativa de cartografar ${ }^{3}$, atravessando a ciência pela porta dos fundos, queremos mergulhar nas experiências e darmos palavra ao que nos afetou. Falar sobre currículos inventados abrindo caminhos de discussão no lugar do afetamento e não da revelação de um currículo que deu certo para ser copiado. Pensamos que não há como investigar as invenções curriculares nos movimentos estudantis, senão pelo campo da experiência e do afetamento.

Vê-se que a linguagem, para o cartógrafo, não é um veículo de mensagens-e-salvação. Ela é, em si mesma, criação de mundos. Tapete voador... Veículo que promove a transição para novos mundos; novas formas de História. [...]. Tudo que der língua para os movimentos do desejo, tudo o que servir para cunhar matéria de expressão e criar sentido, para ele [o cartógrafo] é bem-vindo. (ROLNIK, 2014, p. 65-66).

O texto é, então, organizado a partir do que nos deixou marcas "[...] que formam um relevo - feito de vozes reminiscentes das mais variadas origens, sintonias e estilos, misturando-se e compondo-se - de algumas paisagens contemporâneas" (ROLNIK, 2014, p. 24).

Antes de operar conceitos e dar língua aos afetos que nos pedem passagem, nosso itinerário inicia-se com um breve panorama do que foram as ocupações para situar o leitor. Tratase de uma preocupação de quem ainda sente necessidade de explicar algo, em processo de descolamento dos procedimentos metodológicos, há muito tempo interiorizados, que não cabem na cartografia.

Seguindo o percurso do texto, os dados produzidos com as diversas fontes encontram-se com conceitos filosóficos a fim de entender experiências que desenham cenários de movimentos estudantis. No entanto, esse "[...] entender, para o cartógrafo, não tem nada a ver com explicar e muito menos com revelar. Para ele não há nada em cima - céus da transcendência -, nem embaixo - brumas da essência. O que há em cima, embaixo e por todos os lados são intensidades buscando expressão" (ROLNIK, 2014, p. 66)

Tais cenários giram em torno da ideia de que alguns estudantes não aguentam mais uma engrenagem escolar, chegando à ideia de esgotamento que compõe nossa pergunta problematizadora - a recordar: Quais currículos podem emergir de um esgotamento estudantil?

\footnotetext{
${ }^{3}$ Utilizamos aqui o método da cartografia que entende conhecimento e pesquisa como invenção, mais do que apresentar um mapa, a cartografia se desenha nos movimentos do fazer pesquisa e em suas transformações de paisagem (ROLNIK, 2014).
}

Práxis Educativa, Ponta Grossa, v. 14, n. 3, p. 1085-1103, set./dez. 2019 Disponível em: <http://www.revistas2.uepg.br/index.php/praxiseducativa > 
Por fim, outros cenários produzidos dão corpo ao que entendemos por currículo em composição com as produções curriculares que surgem de um esgotamento estudantil.

\section{Um breve panorama}

Em setembro de 2015, foi anunciado, pela mídia, que estudantes da rede pública estadual paulista seriam transferidos para outras escolas em uma proposta de reorganização da rede de ensino. As escolas seriam divididas por ciclos e, por isso, algumas delas seriam fechadas.

No final de 2015, inspirados no modelo americano, os parceiros do Programa Compromisso SP, atuaram na proposição do projeto de Reorganização das Escolas que previa o fechamento de 92 escolas e a reorganização para segmento único de mais 754 escolas. (PIOLLI; PEREIRA; MESKO, 2016, p. 23).

A Secretaria da Educação buscou algumas formas para legitimar a proposta de reorganização, como o uso de dados coletados pela Fundação Seade (Sistema Estadual de Análise de Dados), que indicavam a diminuição de estudantes matriculados nos últimos anos e, segundo a Secretaria, a existência de salas de aulas ociosas. A Coordenadoria de Informações, Monitoramento e Avaliação Educacional (Cima) indicava que o desempenho dos estudantes que frequentavam escolas de ciclo único era melhor; entretanto, tais dados foram questionados quanto ao rigor e à seriedade em uma análise que desconsiderou inúmeros fatores. A Secretaria também buscou apoio de alguns acadêmicos que defendiam a reorganização e divulgou uma videoconferência do secretário Herman Voorwald às Diretorias de Ensino.

Diante da proposta, um grupo de estudantes organizou um evento no Facebook chamado "Luta pela Educação". Aos poucos, vários estudantes entraram na página para discutir a reorganização e pensar sobre possíveis ações. Em uma das discussões, a página de Facebook da Secretaria da Educação responde aos estudantes ainda na tentativa de defender a reorganização sem abertura para diálogos (CAMPOS; MEDEIROS; RIBEIRO, 2016).

Com o aumento de participantes no evento criado no Facebook, estudantes propuseram como primeira ação realizar manifestações. Assim, durante aproximadamente seis semanas, depois do anúncio da reorganização em setembro de 2015, ocorreram quase 200 formas de protesto (entre protestos simples, manifestações artísticas, passeatas, fechamentos de ruas e atosdebate) nas ruas de São Paulo. Contudo, com o tempo, as manifestações foram perdendo força, com cada vez menos estudantes envolvidos e sem nenhuma alteração da proposta de reorganização por parte do governador Geraldo Alckmin.

A frustração com a intransigência do governo e a falta de atenção da mídia aos protestos desgasta os estudantes, e as manifestações centralizadas são reduzidas cada vez mais a entidades e grupos políticos (partidários ou estudantes) já consolidado no campo de esquerda (governistas ou não). (CAMPOS; MEDEIROS; RIBEIRO, 2016, p. 52).

Naquele momento, a ideia de ocupar as escolas já aparecia na fala de alguns secundaristas. Segundo relatos (CAMPOS; MEDEIROS; RIBEIRO, 2016), parece que a ideia de ocupar as escolas surgiu em um grupo de Whats $A$ pp. Nesse grupo, um manual com experiências e orientações para ocupações foi compartilhado. Esse manual foi traduzido e adaptado pelo 
coletivo O Mal Educado a partir das ocupações que aconteceram na Argentina - Frente de Estudiantes Libertários - e da luta dos secundaristas chilenos - Revolta dos Pinguins.

É importante destacarmos que esse manual foi organizado em novembro de 2013, antes de surgir a ideia de ocupação das escolas durante o movimento de 2015. Além disso, vale explicar que o coletivo O Mal Educado surgiu em 2009 a partir de uma experiência de resistência que conseguiu retirar uma diretora do cargo e, em anos posteriores, iniciou uma articulação entre grêmios de escolas públicas e privadas. O manual torna-se uma das ações do coletivo em um momento emblemático, após as manifestações de junho de 2013, em que vários integrantes estiveram fortemente envolvidos, e, também, contou com as experiências de um dos integrantes que esteve no Chile para conhecer a Revolução dos Pinguins.

A adaptação do manual, além de trazer as experiências do Chile e da Argentina, apresenta um exemplo que ocorreu no contexto brasileiro em 2012, especificamente na Escola Estadual Prof. Luiz Carlos Sampaio, em Nova Andradina, no estado do Mato Grosso do Sul, em que estudantes ocuparam a escola para impedir sua municipalização.

O coletivo O Mal Educado, as organizações no Facebook e os grupos de Whats App foram fundamentais para que as ocupações atingissem um número tão grande de escolas. A primeira escola ocupada foi em Diadema, no dia 9 de novembro de 2015. Os estudantes dessa escola já iniciaram as ocupações a partir do contato com o manual do coletivo O Mal Educado. No dia seguinte, outra escola foi ocupada, a Escola Estadual Fernão Dias. Segundo os estudantes, as duas escolas estavam planejadas para serem ocupadas juntas, mas conseguiram com um dia de diferença já que dependiam de vários elementos para ocupar.

Até o mês de dezembro, mais de 200 escolas foram ocupadas em diversas cidades paulistas, algumas precisaram de mais apoio do coletivo O Mal Educado e outras menos, cada ocupação tinha sua especificidade. Nesse sentido, as doações e o apoio dos vizinhos e dos familiares foram fundamentais para que os secundaristas continuassem nas escolas. Do mesmo modo, o coletivo $O$ Mal Educado e outras organizações foram catalizadores, e não protagonistas, para a luta dos estudantes

Durante esses dois meses, os secundaristas enfrentaram não só a agressividade da polícia militar, mas também a tentativa de partidos políticos e algumas entidades estudantis de assumir a liderança das ocupações. Entretanto, os relatos (CAMPOS; MEDEIROS; RIBEIRO, 2016) mostram o quanto os estudantes se organizaram para que fosse um movimento autônomo com diferentes distribuições de poder.

A autogestão foi uma característica marcante das ocupações. Os secundaristas organizaram-se para a realização de diversas atividades, demonstrando apropriação e cuidado com espaço físico.

\footnotetext{
4 Coletivo formado por estudantes e egressos do Ensino Médio. A ideia de organizar o coletivo surgiu da necessidade de resgatar lutas de secundaristas que saíram da escola, considerando que muitos saem da escola e deixam de compartilhar experiências de luta e de resistência importantes para o avanço de tais movimentos.
}

Práxis Educativa, Ponta Grossa, v. 14, n. 3, p. 1085-1103, set./dez. 2019 Disponível em: <http://www.revistas2.uepg.br/index.php/praxiseducativa> 
O movimento secundarista paulista pode ser definido como um movimento social autônomo porque possui as seguintes características: independência, horizontalidade, autogestão e utilização de táticas de desobediência civil e de ação direta. Os secundaristas que resistiram ao projeto do secretário da educação, Herman Voorwald, e do governador do Estado, Geraldo Alckmin, não são filiados a partidos políticos e não pertenciam a sindicatos ou organizações não governamentais, nem recebiam financiamento de empresas ou de qualquer outra instituição. Muito embora tenham recebido apoio de membros e grupos ligados a partidos e às entidades estudantis, tais como a UBES (União Brasileira dos Estudantes Secundaristas) e UNE (União Nacional dos Estudantes), as ocupações foram inteiramente controladas pelos próprios estudantes. Assim, as ocupações secundaristas foram apartidárias e, ao não recusarem o apoio logístico de partidos, não podem ser descritas como antipartidárias. Em algumas escolas, alguns apoiadores trouxeram bandeiras e demais símbolos partidários, assim que foram vistos pelos secundaristas, que pressentiram a possibilidade de cooptação, a assembleia deliberou pela retirada dos símbolos partidários. (PIOLLI; PEREIRA; MESKO, 2016, p. 24-25).

Muitas escolas divulgaram suas agendas no Facebook e ilustraram como se organizavam diante das demandas:

[EE SELMA MARIA MARTINS CUNHA - FACEBOOK - 30/11/15]

“Amanhã a escola OCUPADA estará 'aberta' e com atividades para receber estudantes da escola, pais, mães e a comunidade. $O$ intuito da ocupação não é fechar a escola e impedir o acesso das pessoas, mas provar que os estudantes podem fazer uma escola melhor. Segue o cronograma de amanhã, dia 01/12/2015:

- 7h00 às 8h00 - Assembleia dos estudantes em ocupação.

- 8h00 - Entrada liberada aos estudantes e comunidade.

- 8h00 às 12 h00 - Quadra aberta/ limpeza dos corredores e pátio.

- 12h00 às $13 \mathrm{~h} 00$ - Almoço (precisamos de doações)

- 13 h00 às $14 \mathrm{~h} 00$ - Rimas freestyle.

- 14h00 às 16 h00 - Quadra aberta/ Roda de música.

- 16h00 às 16h30 - Café da tarde (precisamos de doações).

- 16 h30 às 18 h00 - Debate: machismo e feminismo (com os estudantes da Ufscar).

- 18 h00 - Fechamento da escola.

- 18h00 às 19 h00 - Assembleia dos estudantes em ocupação.

- 19h00 - Jantar (precisamos de doação).

(CAMPOS; MEDEIROS; RIBEIRO, 2016, p. 151).

A força e a organização dos secundaristas contribuíram para a queda da popularidade do governador; assim, Alckmin recuou e assinou o adiamento da proposta e o secretário Herman Voorwald renunciou ao cargo. $\mathrm{O}$ adiamento da reorganização não era o suficiente para tudo que os secundaristas reivindicavam e também que, mesmo com o adiamento, outras ações do governo revelaram uma reorganização velada com o fechamento de algumas salas e outras intervenções nos anos seguintes.

\section{[EE FIDELINO FIGUEIREDO - FACEBOOK - 24/12/15]}

"Ontem, 23/12, desocupamos nossa escola, E.E. Professor Fidelino de Figueiredo, mas isso não significa que a luta acabou, a reorganização NÃO FOI CANCELADA, simplesmente foi suspendida. $O$ fato de estarmos desocupando não significa que estamos deixando a luta e sim que estamos preparando NOVOS MÉTODOS PARA NOVAS METAS! A experiência de conviver todos os dias, 24hrs, com colegas e amigos de escola foi sensacional, aprendi e amadureci muito dentro da mini sociedade que construímos, todos têm um lugar muito especial no meu coração e essa convivência me deixou ainda mais forte e preparada para o que der e ver! NÃ̃ TEM ARREGO!” (CAMPOS; MEDEIROS; RIBEIRO, 2016, p. 294).

Práxis Educativa, Ponta Grossa, v. 14, n. 3, p. 1085-1103, set./dez. 2019 Disponível em: <http://www.revistas2.uepg.br/index.php/praxiseducativa $>$ 
Independentemente das ações do governo que seguiram, não há como negar a importância histórica das ocupações e as conquistas que os secundaristas obtiveram com muita luta. Para além da queda do secretário e do recuo inédito do governador, muitos estudantes tiveram a oportunidade de ampliar o olhar político e de conscientizarem-se de seus direitos e de suas possibilidades de resistência diante de imposições.

Os secundaristas criaram novas escolas, novas relações de pertencimento ao espaço físico, novas formas de organização, de luta e, consequentemente, novos currículos. Trata-se de uma luta que precisa ser compartilhada, divulgada e colocada em debate em diferentes campos, sendo um deles o campo acadêmico que, muitas vezes, afasta jovens de discussões aprofundadas devido às estéticas utilizadas em suas/nossas produções.

\section{Um corpo que não aguenta mais}

"Ando tão à flor da pele que meu desejo se confunde com a vontade de não ser...” Zeca Baleiro

Não são poucos os relatos de situações escolares em que os estudantes escorrem das propostas curriculares, escorrem das disciplinas amarradas, escorrem das tarefas que não fazem sentido. Não são poucos os registros e as respostas "indisciplinadas" de quem não quer ocupar o espaço escolar dessa forma. Do outro lado, também não são poucas as pesquisas em educação que procuram alternativas à melhoria, propondo novas metodologias de ensino, estratégias didáticas ou outras organizações curriculares.

O fato é que os estudantes já não aguentam mais esta engrenagem escolar que não cessa de buscar melhorias dentro do mesmo campo de possíveis. A expressão de David Lapoujade (2002) é reforçada pelos traços à caneta em uma carteira escolar de uma escola estadual de São Paulo (Figura 1).

Figura 1 - Foto de carteira escolar

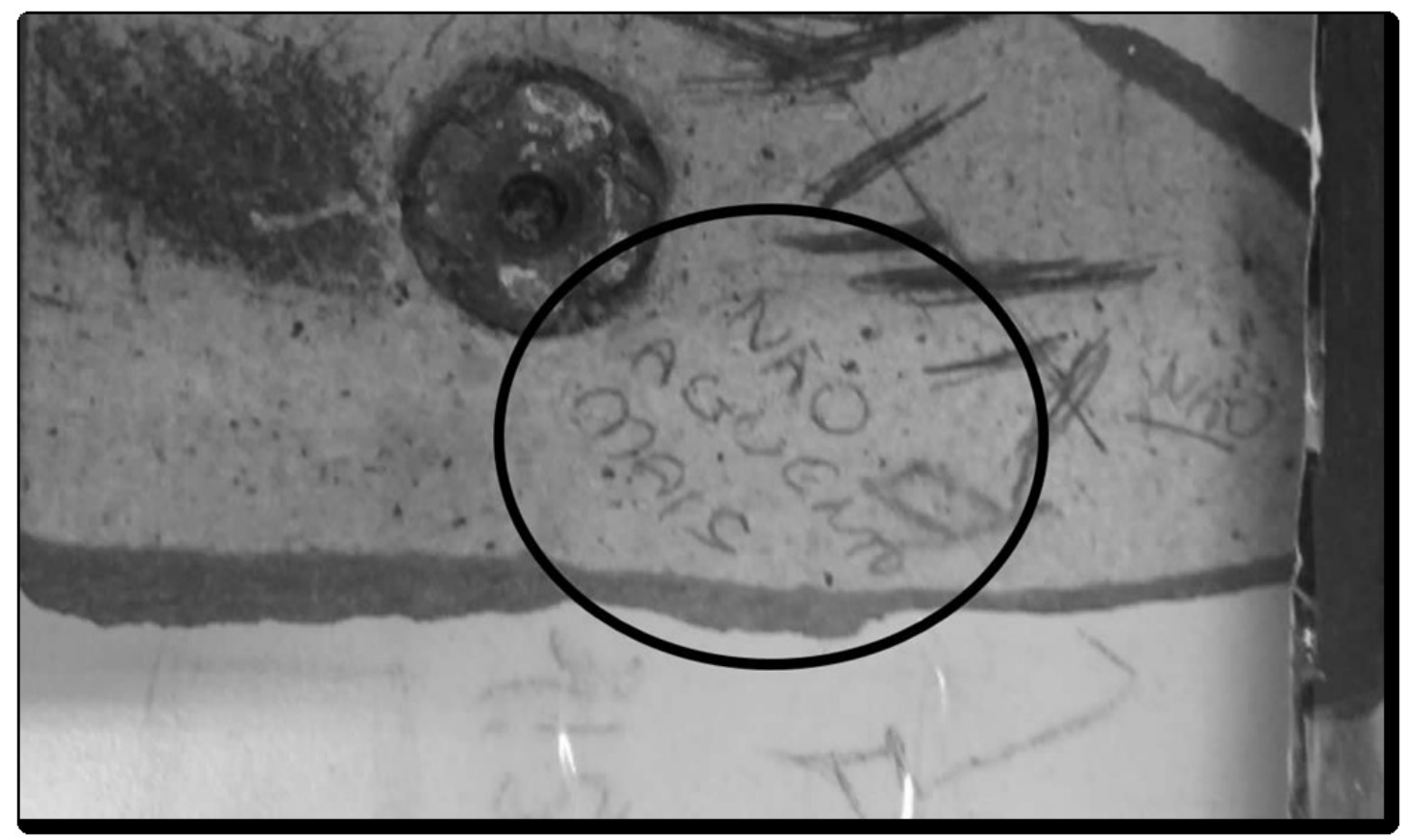

Fonte: Acervo das autoras. Fotografia retirada por pesquisadora durante visita a uma escola estadual de São Paulo. 
Outros relatos em redes sociais ${ }^{5}$ e em entrevistas produzidas ${ }^{6}$ também dão vOz ao esgotamento em relação aos espaços escolares:

Eu particularmente detestava a escola, desculpa a sinceridade, mas eu detestava a escola por ela ser um ambiente muito opressor. (CAMPOS; MEDEIROS; RIBEIRO, 2016, p. 34).

Estudamos em situação precária, no jeito que podemos, em situação que coloca em risco nossa saúde. Tirando o direito do ser humano. [...]. Nas fotos vemos a quadra e o espaço ao seu redor com gramas e moitas com grande volume (o que pode trazer pragas urbanas, trazendo doenças ou até podendo ferir algum aluno ou funcionário). Infiltrações por toda escola. Água sai pela fiação das lâmpadas das salas de aula. Buracos nas paredes com 'remendos', mas sem uma manutenção devida. Banheiros com portas quebradas e sem alguns azulejos nas paredes (o que pode trazer doenças por acumular bactérias). Uma palavra para definir isso: IRRESPONSABILIDADE! Como o governador quer uma reorganização, sendo que nem está organizado? Reflitam sobre isso. (CAMPOS; MEDEIROS; RIBEIRO, 2016, p. 38).

Parece que a escola é um mundo à parte e o que tá ali você não leva porra nenhuma. Você aprende história que é só do passado, e parece que é só do passado. A escola te ensina que é só do passado e que não reflete no presente. Sociologia aparecem umas teorias que você fala 'ah legal!', se o professor for bom, porque tem professor que é uma bosta. Biologia, afff, 'deslenca' da vida, tudo 'deslenca' da vida. E eu acho que esse é um diferencial da ocupação. A ocupação mostrou que a escola pode ser muito mais a minha vida, pode ser mais a minha realidade do que esse mundo abstrato que eles passavam. (Entrevista com secundarista em março de 2018).

A partir desses registros, percebemos um cansaço do formato escolar, das condições precárias dos espaços físicos, das prescrições curriculares e dos temas disciplinares sempre no mesmo campo de possíveis. Um cansaço comumente percebido no contexto escolar.

Lapoujade (2002), ao trazer a ideia de um corpo que não aguenta mais, aprofunda a questão do esgotamento de Deleuze (1992) e questiona “o que o corpo não aguenta mais?”. Para o autor, o corpo não aguenta mais tudo o que se impõe a ele: os processos de adestramento que silenciam corpos para formar uma civilização, como mostrou Nietzsche (1998), e a disciplinarização que torna corpos dóceis, como aprofunda Foucault (1987). Do mesmo modo, o corpo não aguenta mais o que se "[...] submete de dentro. Pois estas mesmas formas passam para dentro, se impõem ao dentro desde que se cria um agente para as agir. Neste instante, a relação muda de natureza; ela deixa de questionar a resistência do corpo no adestramento e o transforma em assujeitamento" (LAPOUJADE, 2002, p. 84).

Os registros anteriores falam de um sufocamento, de um intolerável que chega sem pedir licença, e a sensação de que as possibilidades se esgotaram; é como se todos os clichês sociais não pegassem mais nos estudantes. Tudo que acontece no campo do possível não pega, não cola, se esgota.

Trata-se então de estudantes que não aguentam mais o que os molda por dentro e por fora. Trata-se de estudantes esgotados. No entanto, é importante ressaltarmos que entendemos que os estudantes que se mobilizaram nas ocupações ou que se envolvem ativamente em movimentos secundaristas estão para além de um cansaço. Partimos da ideia de que esse "não

\footnotetext{
${ }^{5}$ Relatos em páginas do Facebook das escolas ocupadas que foram muito movimentadas durante as ocupações para divulgar rotinas e notícias que a mídia não publicava. Tais relatos foram organizados em um livro (CAMPOS; MEDEIROS; RIBEIRO, 2016, p. 38).

${ }^{6}$ Entrevista com secundaristas para pesquisa de Doutorado em andamento.
}

Práxis Educativa, Ponta Grossa, v. 14, n. 3, p. 1085-1103, set./dez. 2019 Disponível em: <http://www.revistas2.uepg.br/index.php/praxiseducativa> 
aguentar mais" refere-se a um estado de esgotamento, pois, embora não suportem mais o formato escolar, ainda continuam ativos; assim, um esgotamento que não anula os desejos.

O cansaço do formato escolar que alguns deles relatam se esgota quando a proposta de reorganização do governo é divulgada. Um acontecimento que vem como a última gota para corpos cansados se transbordarem em esgotamento. Nesse sentido, é necessário repensar esse estado de esgotamento, que não está associado ao cansaço. Como diz Deleuze (1992, p. 67): "O cansado apenas esgotou a realização, enquanto o esgotado esgota todo o possível. O cansado não pode mais realizar, mas o esgotado não pode mais possibilitar".

O cansado pode descansar e voltar a produzir, voltar à atividade e contribuir para o funcionamento da sociedade capitalista. Já o esgotado “[...] pode até combinar ou recombinar as variáveis, percorrê-las exaustivamente, e os termos disjuntivos até podem substituir, mas já não servem para nada” (PELBART, 2016, p. 43). Esse esgotado também não está no lugar de quem jogou a toalha e desistiu da vida, pois: "Não se cai, entretanto, no indiferenciado, ou na famosa unidade dos contraditórios, e não se é passivo: está-se em atividade, mas para nada" (DELEUZE, 1992, p. 69). Trata-se de um esgotado em atividade que se desliga do campo de possibilidades para inventar o impensado.

Os estudantes em estado de esgotamento, como vimos, extraem uma potência superior para ocupar escolas e sobreviver nelas por quase 60 dias a favor da vida, a favor de outra escola recusando clichês e esvaziando os campos de possibilidades para inventar outras. "O corpo aparece aí como sinônimo de uma certa impotência, mas é dessa impotência que ele extrai uma potência superior, nem que seja à custa do próprio corpo. Uma vida" (PELBART, 2016, p. 33).

\section{O que pode um estudante esgotado?}

Reunimos dados produzidos em duas narrativas que ilustram a invenção curricular dos secundaristas potencializada pelo esgotamento ao qual chegaram. Como relatado anteriormente, as narrativas reúnem dados de diversas fontes e nos dão elementos para analisar o processo inventivo curricular.

A primeira narrativa traz uma relação dos estudantes com a direção de uma escola antes das ocupações. Uma relação aparentemente movimentada por autoritarismo que marca esgotamentos e dispara uma movimentação dos estudantes. Tal situação ilustra que movimentos secundaristas já aconteciam e continuam acontecendo em pontos focais para além das ocupações de 2015 e 2016 tão noticiadas.

A segunda narrativa reúne informações sobre os dias de ocupações, incluindo as dificuldades, as formas de organização, incômodos e alegrias constituindo currículos. Diferentemente da primeira narrativa, trata-se de um movimento maior que ganha corpo e potencializa o movimento estudantil historicamente. 


\section{Estudantes também entram em greve!}

Em março de 2015, professores mobilizaram uma grande greve com três meses de duração, à qual alguns professores da nossa escola decidiram aderir. Antes disso, esses professores conversaram com os estudantes sobre o motivo do movimento, construindo debates e despertando nosso interesse para saber mais sobre as condições na educaşão pública. Durante a greve, a vice-diretora informa, na sala dos professores, que substitutos ocupariam as suas aulas. Além de ser uma decisão totalmente autoritária, é uma decisão ilegal.

Os professores avisaram alguns estudantes o que aconteceria e, de forma imediata, resolvemos fazer um abaixo-assinado defendendo a greve. A movimentação foi rápida. Até o fim do intervalo, no dia em que a decisão da direção foi anunciada, todas as salas já tinham feito sua parte. Com a referência de uma ação de uma escola do Rio de Janeiro, a tática escolbida foi de todas as salas ficarem com uma cópia de um abaixo-assinado em defesa da greve e apresentá-la ao professor substituto para que a aula não pudesse ser dada. Se a reposta fosse negativa, os estudantes iriam até a direção e repetiriam o procedimento com o abaixo-assinado. Em mais um caso negativo, todos os estudantes caminhariam até o pátio e ficariam até o fim do horário de aula não deixando que as aulas acontecessem.

Conseguir as cópias do abaixo-assinado em tão pouco tempo foi um primeiro obstáculo: tirar xerox sem dinheiro, conseguir descontos, pesquisar o melhor lugar, utilizar nossos contatos, distribuir nas salas...

Com tudo rapidamente organizado, na primeira oportunidade, uma sala executa o planejado, com alguns erros. Estudantes, após uma resposta negativa à apresentação do abaixo-assinado, descem para o pátio, de um modo não muito organizado, ainda sem muito bem saber como tudo poderia acontecer. Mas, mesmo sendo um movimento inicialmente desorganizado, foi o bastante para a direção ter um surto de autoritarismo e passar em todas as salas do Ensino Médio dizendo frases como: "querem ter voz na escola? Mude de escola", "minha escola acontece da forma que quero", "não tá contente, mude de escola", "aluno não tem voz aqui".

Após diversos debates na sala de aula, dois estudantes [eu era uma] sobem para a sala da direção para conversar. Em meio a conversa, as frases acima aparecem com outras palavras, além de uma leitura de conjuntura totalmente contrária aos professores. O fim da conversa acontece quando a vice-diretora afirma que passará por cima da lei e, se os estudantes não estivessem contentes, que fizessem uma greve, mas que ela nunca tinha visto uma greve de estudantes. Então, uma aluna responde: você verá agora!

Chegando ao pátio, uma das cenas mais bonitas que vivi na escola: havia estudantes de três salas sentados nos esperando para dar força, e foi nesse momento que confirmamos a nossa "greve". Paralisamos por três dias em apoio aos professores. Era uma prévia da potência desse movimento. À tarde, no mesmo dia, aconteceu uma Assembleia no Vão do Masp e professores e estudantes da nossa escola compareceram.

Na confraternização, após o término da manifestação, uma foto coletiva [Figura 2] é tirada e mandada ao grupo de Whats App dos professores da escola. Um desses professores entregou essa foto e prints da conversa ao diretor. Na sexta-feira dessa mesma semana, o diretor reúne os professores para mostrar a tal foto e apontar uma aluna como a organizadora da paralisação de três dias. Anterior a essa reunião, houve uma conversa em que o diretor ameaçou de tirar a aula de uma professora que estava na foto.

Práxis Educativa, Ponta Grossa, v. 14, n. 3, p. 1085-1103, set./dez. 2019 Disponível em: <http://www.revistas2.uepg.br/index.php/praxiseducativa> 
Figura 2 - Estudantes em Assembleia para organizar a paralização de três dias na escola

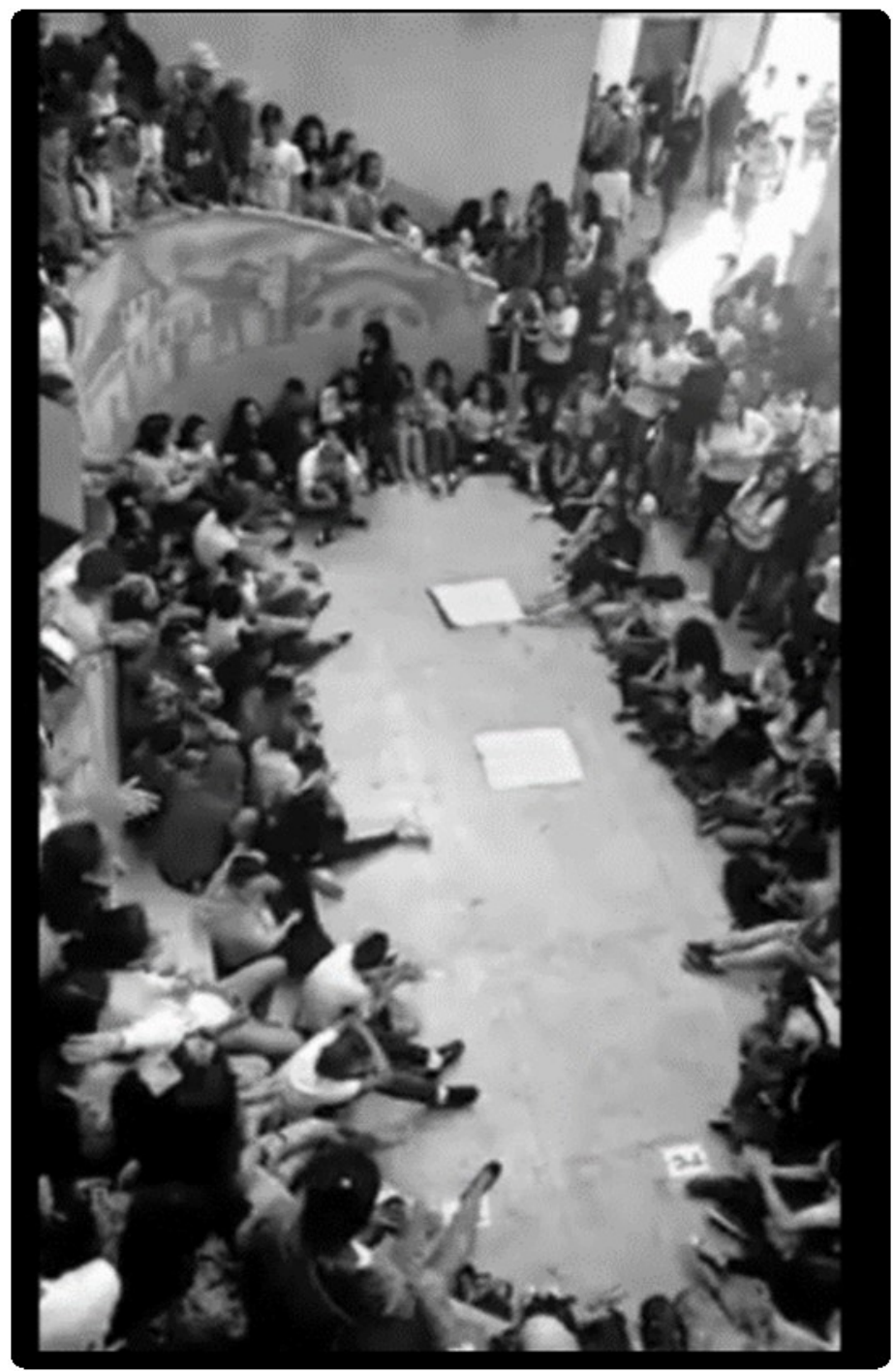

Fonte: Acervo das autoras.

Essa paralisação acarretou perseguições a professores e estudantes. Mas o maior saldo era a solidificação de um grupo empenhado em lutar por aquele espaço. Eu começava a entender o que era ser uma secundarista, quando a gente passa por essas coisas parece que não dá mais para viver sem lutar. Talvez tenha percebido que eu já lutava há muito tempo.

Após nossa paralização, durante um ano e meio, outras coisas aconteceram: abusos de autoridade, usos indevidos dos espaços escolares, bombas, viatura de policia, nossa presença na Diretoria de Ensino, medo, boicote ao Saresp, aluno preso e perseguições. E nós, em luta! Foi assim que a direção saiu e foi para outra escola. Avaliamos em coletivo que o nosso movimento, todas as nossas lutas pressionaram para que isso acontecesse. É uma vitória nossa.

Com grande sorte, o novo diretor da escola tem outra visão de educação e de participação dos estudantes. Sabendo disso, ex-estudantes retornaram à escola para fazer o que queriam e não podiam. Nosso primeiro projeto foi o retorno do cursinho pré-vestibular e o projeto de grafite dentro da escola. O projeto foi organizado em dois dias de cursos para as crianças e, no terceiro dia, colorimos a escola que era cinza [Figura 3].

Práxis Educativa, Ponta Grossa, v. 14, n. 3, p. 1085-1103, set./dez. 2019 Disponível em: <http://www.revistas2.uepg.br/index.php/praxiseducativa> 
Os dois dias de cursos foram repletos de crianças encantadas pelo spray. No dia de colorir a escola, os exestudantes apareceram, mostrando como cada um ama e acredita naquele espaço negado por tantos anos. Nos sentimos realizados, mas ainda falta muito para esse espaço se tornar o que queremos.

Figura 3 - Projeto grafite na escola ${ }^{7}$
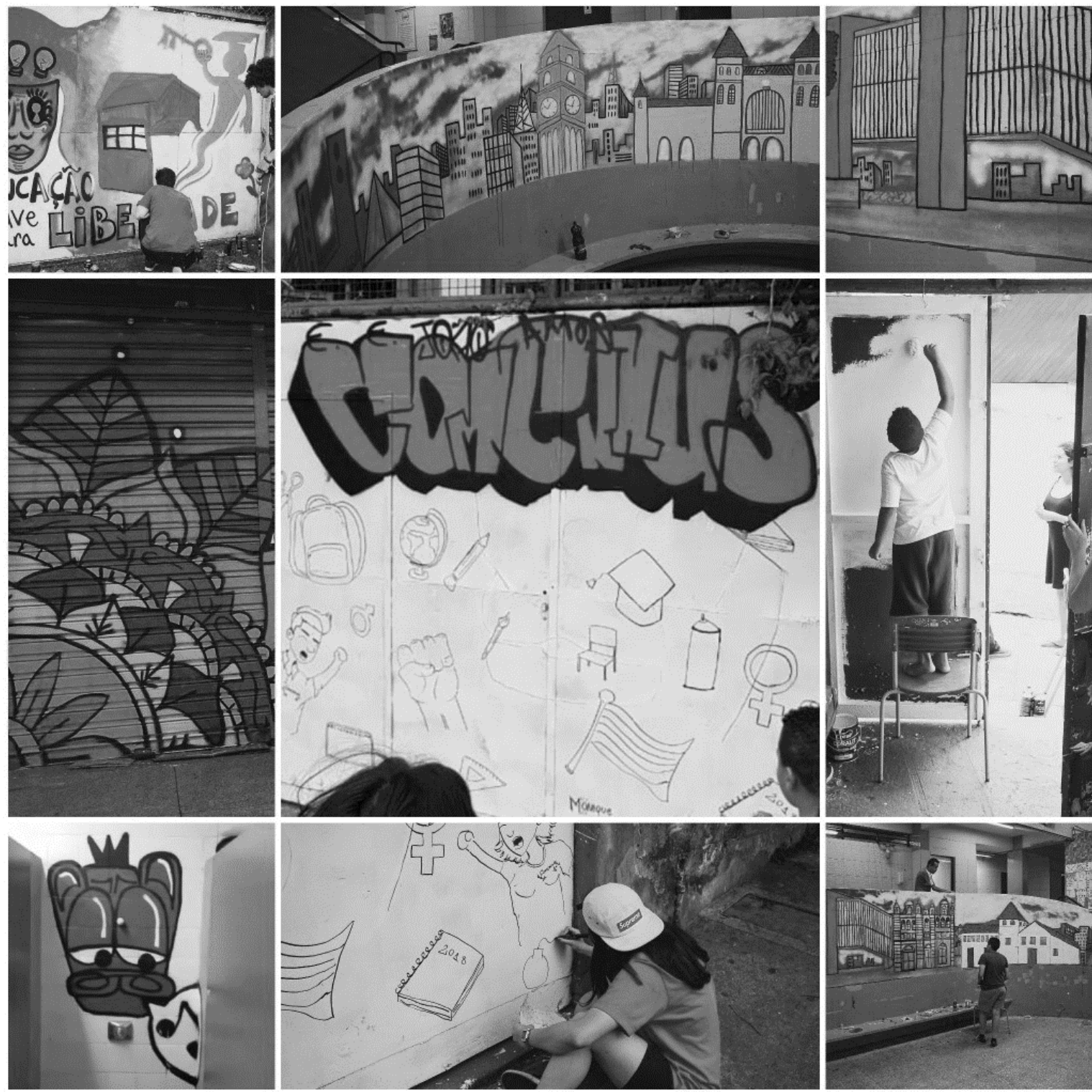

Fonte: Montagem de fotos retiradas por estudantes.

$* * *$

Estudantes silenciados pela direção da escola apoiam a greve dos professores, ultrapassam os limites da escola para ocupar ruas e dar voz aos seus esgotamentos que se compõem com as difíceis condições de trabalho dos professores. Estudantes afetados com a posição da escola em relação aos incômodos dos professores conseguem paralisar uma escola por três dias. Estudantes que inventam outra organização para paralisar uma escola quando um planejamento momentâneo não é cumprido por eles mesmos, porque descemos para o pátio, de um modo não muito organizado, ainda sem muito bem saber como tudo poderia acontecer.

${ }^{7}$ A foto original é colorida, os grafites colorem os espaços cinzas.

Práxis Educativa, Ponta Grossa, v. 14, n. 3, p. 1085-1103, set./dez. 2019 Disponível em: < http://www.revistas2.uepg.br/index.php/praxiseducativa> 
Essa mobilização sem endereço fixo, mas localizada no coletivo de estudantes, se compõe com o paradoxo entre forte e fraco, já que os estudantes enfraquecidos e silenciados pela engrenagem escolar agiram com força. Tal paradoxo é tratado por Bárbara Stiegler, como nos lembra Lapoujade (2002, p. 88): “[...] o que faz a fraqueza do forte é que ele se esforça para preservar, e mesmo aumentar, sua vulnerabilidade; controlando seu grau de exposição às feridas do fora; se protegendo das agressões mais grosseiras, ele pode se abrir às feridas mais sutis".

É nesse sentido que um estudante esgotado pode muito! Um fraco-forte que inventa outras possibilidades e colore a escola que era cinza. Quando falamos de esgotamento como potência de criação de outros possíveis não estamos no lugar do abstrato, estamos falando desses escapes concretos que o esgotamento provoca. Afinal, quando a gente passa por essas coisas, parece que não dá mais para viver sem lutar.

Se partimos da ideia de que o estudante tornou-se esgotado e se assumirmos o estado de esgotamento como condição de seus corpos, como propõe Lapoujade (2002), podemos considerar que os estudantes estão a todo momento inventando outras possibilidades, seja em escapes na sala de aula, em uma paralisação da escola por três dias, em produções de grafites nos muros, seja com as ocupações estudantis de 2015 e 2016 que marcaram história.

É como se tocássemos a própria definição do corpo: o corpo é aquele que não aguenta mais, aquele que não se ergue mais.

De fato, embora aquilo que designamos sob o nome de Fato, na ausência de um nome melhor, pareça "moderno", é evidente que é desde sempre que o corpo não aguenta mais. (LAPOUJADE, 2002, p. 82, grifo do autor).

Os estudantes em estado de esgotamento abrem caminhos (im)possíveis nas micro ações nas salas de aula. No entanto, para Suley Rolnik (2018) os novos tipos de ativismos entrelaçam as esferas macro e micropolíticas; por isso, as ocupações ganham destaque.

Se estudantes em uma escola estadual paralisam as aulas por três dias e inventam uma organização para escapar de seus silenciamentos, o que podem mais estudantes esgotados nas ocupações estudantis de 2015 e 2016 que marcaram a história?

Além de não submeter-se à institucionalização, o novo tipo de ativismo não restringe o foco de sua luta a uma ampliação de igualdade de direitos - insurgência macropolítica pois a expande micropoliticamente para a afirmação de um outro direito que engloba todos os demais: o direito de existir ou, mais precisamente, o direito à vida em sua essência de potência criadora. [...]. A apropriação do direito à vida é diretamente encarnada em suas ações: é no dia a dia da dramaturgia social que essas ações acontecem, buscando transfigurar seus personagens e a dinâmica da relação entre eles. $[\ldots]$.

O novo tipo de insurreição, com seus dispositivos macro e micropolíticos manifesta-se com especial vigor entre as gerações mais jovens, sobretudo nas periferias dos centros urbanos. (ROLNIK, 2018, p. 24-25).

O exercício agora é perceber essas invenções - que vêm dessa potência criativa da qual fala Suely Rolnik (2018) - de outros possíveis a partir do que está dito, na superfície, sem buscar o que há atrás do relato, ou buscar por essências furadas. Ao olhar para as invenções relatadas, iniciamos o deslocamento para nosso foco de interesse: as produções curriculares.

Práxis Educativa, Ponta Grossa, v. 14, n. 3, p. 1085-1103, set./dez. 2019 Disponível em: <http://www.revistas2.uepg.br/index.php/praxiseducativa > 


\section{Currículo-gente}

Macarrão de novo?

Não pisa, acabei de lavar o banbeiro!

Gente, tá cheio de polícia lá fora, tem jornalista, tem estudante, tem família, tem bandeira de partido... tem muita gente no portão da escola, o que a gente faz?

Desculpe, senhor diretor, mas não vamos deixar você entrar, você chegou atrasado!

Vocês não podem entrar, a escola é nossa!

Policial, cuidado! Essa cadeira é da escola!

Oh, eu acabei de passar pano, não pisa nessa porra, fica na quadra!

Pessoal, jogral...

Nossos dias eram assim. Cozinhar com as doações, jogar comida ruim fora? Nem pensar, tínhamos que comer aquilo mesmo. Como preparar macarrão pra tanta gente? À noite, muitos iam embora, nunca falávamos para os policiais e para mídia quantos estudantes tinham lá dentro, já que, às vezes, tinham só dois ou três, e eles não poderiam saber disso.

As primeiras assembleias duravam muito tempo, oito horas de discussão, a gente usava o tempo para desabafo. Era tanta coisa que incomodava que a gente tratava entre a gente, por besteira, coisas da idade ou do momento. É muito foda pensar no coletivo. Isso era o mais difícil.

Assembleia de novo! Tudo era assembleia, tínhamos que resolver o que comer, como se proteger dos partidos políticos, dos uspianos, de todas as organizações que queriam acabar com o movimento ou tomar à frente dele. Tínhamos que decidir as rotinas do dia, decidir quem poderia entrar ou não, quem aceitaríamos para aulas voluntárias ou intervenções artísticas.

Era muita coisa. Mas, lá na nossa escola ocupada, não tinham muitos professores voluntários, isso era nas escolas mais conhecidas ou de centro. Até nas ocupaçôes as escolas mais periféricas sofriam, não chegavam doações, não chegavam professores, não chegavam advogados ou outras pessoas para ajudar. Mas os secundaristas de outras escolas ajudavam, dividiam comida e cigarro - sim cigarro também, por que não? -, era sempre entre a gente mesmo.

O que é difícil das pessoas entenderem é que não somos revolucionários como alguns pensam, que não vestiamos esse uniforme de estudantes politizados que lutavam conscientemente por um ideal, on que estávamos dispostos a ter aulas sobre tudo, como bons militantes cultos e inteligentes. Só queríamos que as escolas não fossem fechadas, só isso.

Tinham dias que a gente só queria escutar um funk, conversar sobre nossas vivências, não queríamos uma aula "cult" sobre o feminismo. Lógico que hoje sabemos a importância de vários movimentos e temáticas, mas não somos esses personagens "salvadores da educação" criados por todos, demonizados por uns e endeusados por outros. Somos secundaristas com medos, dores, alegrias e desejos.

Era legal sentar, conversar, escutar uma música e falar sobre nada. Era legal lavar o corredor e enchê-lo de espuma. Imagina o que era um corredor com espuma! Era legal ver espacos da escola que ficavam vazios e agora estavam cheios de gente, da gente. ...sabemos que nada disso cai no vestibular, mas era isso que nos fazia bem. Isso nos aproximou, a gente aprendeu a olbar o outro de outro jeito, a gente aprendeu a ser gente. Talvez seja isso que o estado queira negar, estudantes que sejam gente e não número.

Mas também aprendemos outras coisas: a importância de falar bonito para ganhar credibilidade, ninguém mais convence a gente com palavras dificeis; como organizar comissões para a escola funcionar; conbecer estratégias de partidos políticos; conbecimentos de leis para nossa proteção e várias outras coisas. A gente tinha que aprender esse tipo de coisa para conseguir sobreviver na escola.

Práxis Educativa, Ponta Grossa, v. 14, n. 3, p. 1085-1103, set./dez. 2019 Disponível em: <http://www.revistas2.uepg.br/index.php/praxiseducativa> 
Cada escola é uma escola, os acontecimentos, os apoios e as retaliações foram diferentes e com intensidades diferentes. E nós também tínhamos motivos diferentes para estar lá. Muitos começaram com a luta para não fechar a escola e isso foi sendo tomado por todos, mas tinham aqueles que estavam lá porque não tinham comida em casa, e lá tinha macarrão! Outros porque as brigas em casa estavam insuportáveis ou por estarem passando por momentos pessoais difíceis. Também tinham aqueles apoiados pelos pais e já experientes em movimentos políticos.

Estar naquele espaço, mesmo com todas as dificuldades de se manter lá dentro, era melhor do que estar em outros lugares, a gente se acolhia, se ajudava, se tocava, se olhava. A gente percebia que era gente, a gente ganhava vida, a escola ganhava vida. É, a escola comeşava a faz̧er algum sentido.

Uma rotina-outra produzida, estudantes esgotados encontram outras formas de ocupar as escolas inventando currículos sem listas de contéudos previamente organizadas. A ausência das listas de conteúdos não implicava na contestação da importância de tantos conhecimentos explorados na escola, já que, em meio à rotina, também aconteciam aulas de Matemática, Química e Física em função das necessidades de alguns estudantes com o vestibular. Trava-se então de um currículo inventado com Matemática, Química, mas também com discussões sobre o feminismo e com o preparo de macarrão! Um currículo movido pelas demandas e pelas experiências.

Partindo das ideias deleuzeanas, entendemos que inventar currículos é abrir-se para experiências e que tais experiências podem ser potencializadas pelo estado de esgotamento. Assim, da experimentação fez-se currículo! Fez-se currículo-macarrão, currículo-portão, currículo-assembleia... currículo-gente. Um currículo-gente que se dá na nova-outra relação com o outro e com o espaço. O encontro de estudantes com outros estudantes, com o macarrão, com o funk e com os portões amarrados por cadeados produziu acontecimentos. Estudantes esgotados compõem-se nos encontros com pessoas e objetos de outros modos. Experimentação que surge do encontro dos estudantes com outros estudantes, com objetos, com espaços, com macarrão ou com música. Experimentação que aumenta potência de agir, que vai do esgotamento à invenção de currículos.

Fazer do currículo, pois, uma pura experiência spinoziana. Deleuziana. Cultivar os bons encontros. Aqueles que nos ajudam a nos apartar do efêmero e do contingente para experimentar um gostinho do infinito e do eterno. Criar afectos e perceptos que, como as obras de arte, sejam como experiências de eternidade. Porque tem a imanência de uma vida, um currículo assim jamais deixa o solo. Mas ele se toma leve. (TADEU DA SILVA, 2002, p. 56).

Em um mesmo espaço, com as mesmas pessoas, os mesmos objetos, os mesmos corpos, mas outras composições. Estudantes compõem-se em um currículo-gente que não sabe muito bem como caminhar, que testa o que fazer em longas oito horas de assembleia e, depois disso, não cumpre o que foi planejado. Um currículo-gente que se importa em abrir o olhar para o incômodo do outro antes de discutir uma fórmula matemática, mas que discute a fórmula matemática também. Um currículo-gente que se abre aos desejos. Um currículo-gente em que cabe o funk e a discussão sobre feminismo, que cabe as brincadeiras no corredor coberto por espuma e as estratégias de proteção contra àqueles de fora que queriam ganhar vantagens com a situação, ou até mesmo que se impuseram com força bruta. Um currículo-gente que aprende o que pode um falar bonito e a importância de organizar as doações para todo mundo ter o que comer lá dentro.

Inventar currículos por meio dos escapes. Isso também é currículo.

Práxis Educativa, Ponta Grossa, v. 14, n. 3, p. 1085-1103, set./dez. 2019 Disponível em: < http://www.revistas2.uepg.br/index.php/praxiseducativa > 
[...] pensar um novo estilo para um currículo. Fazer passar nesse território alguma energia. Deixar escapar, vazar sensações: uma corrente de energia. Fazer cortes provisórios na multiplicidade existente somente para espalhar, potencializar e seguir outras direções. Mostrar nossos pensamentos e paixões concretas que, em um currículo, arrancam-nos de nossa paralisia e dos poderes que fazem complô para que não pensemos nada. (PARAÍSO, 2010, p. 602).

Por que não considerar que todas essas experiências compõem currículo? Se currículo pode ser um artefato que dialoga com as diversas possibilidades de desejo e de modos de vida, então o currículo-gente produzido nas ocupações faz muito sentido.

A potencialidade desse currículo-gente nasce da experiência de um corpo ativo, mas esgotado de tudo que o coage. No entanto, pensamos que esse tal currículo-gente é relâmpago, já que, ao mesmo tempo que cria outras formas de ser escola, se esvai quando a experiência termina. O funk, o macarrão, a espuma e também os medos, os desejos, talvez os toques e os olhares não estão nos currículos prescritos promulgados nos documentos oficiais brasileiros, que colaboram para os processos de adestramento e docilização de corpos. A maioria das escolas voltaram à "normalidade" após as ocupações.

Mesmo com algumas tímidas tentativas de reconstruir currículos a partir desse movimento histórico, não é possível reproduzir essas experiências e apresentar novas cartilhas curriculares. Ao colocar experiências como essas em documentos que têm a finalidade de padronizar currículos, o currículo-gente já se esvai. Isso porque trata-se de um currículo que se escreve nos vazamentos e não na padronização, e, quando há tentativa de padronização, já não é mais o mesmo currículo.

Partilhar! Compartilhar! Viajar sem mapas prévios! Fazer outros traçados! Fugir! Fazer composições e conexões! Inventar a cada vez suas orientações. Aprender! Gerar possibilidades de aprendizagem em contextos insuspeitados. Aumentar a potência de agir. Metamorfosear! Movimentar o próprio pensamento. Escapar das tentativas de captura. Deslizar. Fugir e criar um outro currículo que é e será único, inapreensível, incomunicável. (PARAÍSO, 2010, p. 602).

Um currículo-gente com prazo de validade, único e inapreensível, que deixa seus rastros e certamente rendem algumas capturas. Depois de tudo isso as histórias não serão mais contadas do mesmo jeito. Do mesmo modo que as ocupações marcam historicamente no aspecto macro, no aspecto micro, cada um destes estudantes que passaram pelo movimento ou que produziram outros vazamentos não noticiados, também não contarão suas histórias do mesmo jeito.

Vale ressaltarmos que não é uma transição do currículo tradicional engessado para um currículo-gente flexível. Não é um movimento dicotômico estanque. Os currículos escolares previstos misturam-se na invenção curricular no período das ocupações. Trata-se de um movimento complexo de invenção em que agenciamentos molares e moleculares se misturam:

Cada indivíduo deve lidar com esses grandes agenciamentos sociais definidos por códigos específicos, que se caracterizam por uma forma relativamente estável e por um funcionamento reprodutor: tendem a reduzir o campo de experimentação de seu desejo a uma divisão preestabelecida. Esse é o pólo estrato dos agenciamentos (que são então considerados "molares"). Mas, por outro lado, a maneira como o indivíduo investe e participa da reprodução desses agenciamentos sociais depende de agenciamentos locais, "moleculares", nos quais ele próprio é apanhado, seja porque, limitando-se a efetuar as formas socialmente disponíveis, a modelar sua existência segundo os códigos em vigor, ele aí introduz sua pequena irregularidade, seja porque procede à elaboração involuntária e tateante de agenciamentos próprios que "decodificam" ou "fazem fugir" o agenciamento estratificado [...]. (ZOURABICHVILI, 2004, p. 9).

Práxis Educativa, Ponta Grossa, v. 14, n. 3, p. 1085-1103, set./dez. 2019 Disponível em: < http://www.revistas2.uepg.br/index.php/praxiseducativa> 
Assim, os currículos produzidos durante as ocupações inventam-se a partir de uma molaridade das estruturas escolares conhecidas ao mesmo tempo que fazem escapar molecularidades que fogem, desequilibram e rompem estruturas.

\section{Para encerrar}

Em nosso rápido itinerário, buscamos compor nossas experiências com os arcabouços filosóficos. Ao transitar neste texto, ainda esburacado, percorremos as noções de esgotamento e currículo entrelaçadas às (im)possibilidades inventadas pelos estudantes nos espaços escolares tão consolidados. O novo ativismo dos estudantes-secundaristas em esferas micro e macropolíticas compuseram-se em currículos-outros inventados, recheados de gente e de sensibilidade.

Vimos que um estudante esgotado, que está para além ou para aquém do cansaço, pode muito! Pode criar outra escola e produzir outros currículos. Vimos que esse modo de organização escapa do campo de possíveis, o qual não conseguimos enxergar quando estamos cansados.

Em meio ao não cumprimento de planejamentos, tanto nas ocupações como na greve organizada pontualmente em uma escola estadual de São Paulo, os estudantes organizam-se de outros modos, está no lugar dos afetos, do olhar o outro, do sentir o que precisa ser feito naquele momento, ainda que seja fugindo da direção e (re)voltando-se de outro modo.

Por que não considerar um currículo-gente que vazou? Organizar-se de um modo outro não é também currículo? Preocupar-se com a alimentação e com o funk não pode ser currículo? Articular defesa à entrada às vezes (muitas) da polícia não é currículo? $\mathrm{O}$ chão da escola com colchões ou com espuma pode ser currículo?

Há quem diga que depois das ocupações tudo continuou igual. Estudantes que passaram por isso ainda têm dificuldades de falar sobre como as ocupações chegaram ao fim. Há estudantes que carregam no corpo marcas de repressão. Há estudantes que carregam no medo marcas de perseguição. Há estudantes que carregam no esgotamento potência de criação. Por tudo isso, podemos dizer que tudo não continuou igual, ainda que as escolas tenham voltado a seguir, ou melhor, tentar seguir currículos prescritos obrigatórios. Entretanto, quem passou por essas experiências não atravessará mais o mundo do mesmo modo, tampouco os que se envolveram com o movimento estudantil de algum modo.

Nada permanece igual, os estudantes-secundaristas que ocuparam escolas, ruas e tomaram posse da própria vida já são outros. Abriram-se à experimentação, chegaram ao fundo do poço em um esgotamento que parecia não ter saída para inventar um novo, um novo efêmero, finito, mas ilimitado em suas reverberações. Já somos outras.

\section{Referências}

CAMPOS, A. J. M.; MEDEIROS, J.; RIBEIRO, M. M. Escolas de luta. São Paulo: Veneta, 2016. (Coleção Baderna).

DELEUZE, G. L’épuisé. Tradução de Lilith C. Woolf e Virginia Lobo. Paris: Minuit, 1992.

FOUCAULT, M. Vigiar e punir: nascimento da prisão. Tradução de Raquel Ramalhete. Petrópolis: Vozes, 1987. 
LAPOUJADE, D. O corpo que não aguenta mais. In: LINS, D. (Org.). Nietzsche e Deleuze: que pode o corpo. Rio de Janeiro: Relume-Dumará, 2002. p. 81-90.

LATOUR, B. Ciência em ação: como seguir cientistas e engenheiros sociedade afora. São Paulo: Editora UNESP, 2000.

LATOUR, B. Como falar do corpo? A dimensão normativa dos estudos sobre a ciência. In: ARRISCADO, J.; ROQUE, N. R. (Orgs.). Objectos impuros: experiências em estudo sobre a Ciência. Porto: Edições Afrontamento, 2008. p. 39-61.

NIETZSCHE, F. Genealogia da moral: uma potência. Tradução de Paulo César de Souza. São Paulo: Companhia das Letras, 1998.

PARAÍSO, M. A. Diferença no currículo. Cadernos de Pesquisa, São Paulo, v. 40, n. 140, p. 587-604, maio/ago. 2010. DOI: http://dx.doi.org/10.1590/S0100-15742010000200014

PELBART, P. P. O avesso do niilismo: cartografias do esgotamento. 2. ed. São Paulo: N-1 edições, 2016.

PIOLLI, E.; PEREIRA, L.; MESKO, A. S. R. A proposta de reorganização escolar do governo paulista e o movimento estudantil secundarista. Crítica Educativa, Sorocaba, v. 2, n. 1, p. 21-35, jan./jun. 2016. DOI: http://dx.doi.org/10.22476/revcted.v2i1.71

ROLNIK, S. Cartografia sentimental: transformações contemporâneas do desejo. Porto Alegre: Sulina; Editora da UFRGS, 2014.

ROLNIK, S. Esferas da insurreição: notas para uma vida não cafetinada. São Paulo: N-1 Edições, 2018.

SAN SEGUNDO, M. A.; SEVERO, R. G. Repensando o currículo a partir da ocupação de escolas. Práxis Educativa, Ponta Grossa, Ahead of Print, v. 14, n. 3, p. 1-17, set./dez. 2019.

TADEU DA SILVA, T. A arte do encontro e da composição: Spinoza + Currículo + Deleuze. Educação \& Realidade, Porto Alegre, v. 27, n. 2, p. 47-54, jul./dez. 2002.

ZOURABICHVILI, F. O vocabulário de Deleuze. Rio de Janeiro: Relume Dumará, 2004.

Recebido em 31/03/2019

Versão corrigida recebida em 31/08/2019

Aceito em 05/09/2019

Publicado online em 10/09/2019

Práxis Educativa, Ponta Grossa, v. 14, n. 3, p. 1085-1103, set./dez. 2019

Disponível em: <http://www.revistas2.uepg.br/index.php/praxiseducativa> 